\title{
THE EFFECT OF TEACHING BY (MOBILE LEARNING) IN UNIVERSITY STUDENTS'S ACHIEVEMENT
}

\author{
Omar M. K. Mahasneh \\ PhD., Department of Basic and Applied Science, Faculty of Shobak University College, AL-Balqa Applied University, \\ Jordan
}

\begin{abstract}
There have been efforts to investigate the effect of teaching by using mobile learning in university student's achievement. However, studies examining effect of teaching by using mobile learning in university students are, thus far, rare. This study adopted a quasi-experimental design with two types of teaching methods. One research group was assigned to the mobile learning teaching Method $(n=25)$ and the other to the conventional teaching Method $(n=25)$. A multiple-choice test was developed in Unit introduces technology in course of pre-vocational education technology, Within the Bachelor of pre-vocational education program at Shobak university college. The results showed that the mobile learning teaching method was more effect than the conventional teaching method in the achievement of university students.
\end{abstract}

\section{KEYWORDS}

Mobile Learning, University Students, Achievement

\section{INTRODUCTION}

In 1970, the concept of M-learning (Mobile-learning) appeared by Alan Kay, He developed a portable and hands on personal computer (Dynabook) it was intended to develop children's abilities in dealing with digital technology (Pirttiaho, Holm, Paalanen, \& Thorstrom, 2007; Saylor, 2012; Singh, 2010; Pimmer, \& Grohbiel, 2008). In 1994, Mitsubishi Electric Corp designed the first smart phone (IBM Simon), since that date telecommunications companies have started developing (smart phones) it was used in education under the name mobile-learning. The educational term (mobile learning) has become a key topic in the educational and social sciences, as mentioned by many researchers (Maxwell, 2006; Masters \& Ngambi, 2007; Al Tawarah, Mahasneh and Al-Hawartheh, 2017; Mahasneh and Murad, 2014). After studying the theoretical literature, mobile Learning meaning the use of mobile information technology and mobile devices in the education process (Pimmer and Grohbiel, 2008; Cook and Pachler, 2012). Were explained of mobile learning that makes the learner enjoy in the study successfully. Chan (2011) carried out to mobile learning must be part of school and universities, Therefore, the current study aimed at detection to investigate the effect of teaching by using mobile learning in university students achievement.

\subsection{Theoretical Background}

Many researchers have confirmed as (Keegan, 2005; Swan, 2005; Moore, 2009; Chan, 2011; Jump\& Cochrane, 2013; Crescente \& Lee, 2011; Crompton, 2013; Cook \& Pachler, 2012) that mobile learning achieves the following advantages (Facilitates access management and exchange of information, Develop student's creativity and motivation, Encourage student learning and enhance their performance, Encourages individual learning, Encourages communication between students, faculty and students with same, Provides a variety of resources used (photos, videos, applications), Allows the application of a wide range of learning strategies, Facilitates student assessment, Make education more fun and Facilitate distance learning. The researcher conducted the procedures (Development of the unit of activities to be implemented using mobile learning, Design a training program that includes sessions, Providing mobile learning for each student in the experimental group, Conducting unit content analysis to make a test specification tablet, Achievement test design, Identification of two groups to be taught in the conventional method and mobile learning). 


\subsection{The Researches about Effect of the Mobile Learning}

The researcher after studied the theoretical literature and previous studies did not find studies on the subject of determining the effect of teaching by using mobile learning in university student's achievement. Studies focused on a set of things related to the subject of the study. Mahdi (2016) carried out a study aimed at investigating the effectiveness of mobile learning service SMS in acquiring and retaining the instructional technology concepts among the College of Education Students at Al-Aqsa university. The study results revealed that there are statistically significant differences at the level of significance $(\alpha=0.01)$ between the average of the grades of the experimental group and the average of the grades of the control group in favor of the experimental group in the technological concepts test. Al-Monim (2017) conducted a study aimed at identifying the effectiveness of smart phones employment in developing of self-learning skills and electronic communication among students of the Faculty of Education at Al-Aqsa University in Palestine. The results showed that there are statistically significant differences reading the marks obtained by the university students in terms of the development of self-learning skills and electronic communication scales on the pre-and post-tests. Mileva (2011) carried out a study aimed at investigating the Effectiveness of Mobile Learning in the Form of Performance Support System in Higher Education. the result showed that confirmed by the students who indicate that the use of a mobile device did not hamper their learning.

All previous studies focused on learning the effect of mobile learning on some variables (self-learning skills, Performance Support System, instructional technology concepts). The present study differs from previous studies in that it is the only studies that researches investigate the effectiveness of the mobile learning in university student's achievement.

\section{THE PRESENT STUDY}

The aim of this study is to contribute to the knowledge of the effect of teaching by using mobile learning in university student's achievement. The research was conducted on (50) students as experimental group and control. This study is one of the rare studies in this Domain; I distinguished to structure Instrument for achievement test. The study attempted to answer the following questions: Is there a statistically significant $\alpha=0.05$ in differences between the average scores of the students of the experimental group and the students of the control group in the test of achievement?

\section{METHOD}

\subsection{Research Design}

The study adopted a quasi-experimental design. The Individuals for this study consisted of (50) students, (25) Experimental and (25) Control. The researcher first made an arrangement to work with the dean of Shoubak University College For agreeing to conduct the study. The researcher then structures the Instruments and verified their Validity and Reliability, and then applied to the Individuals of study.

\subsection{Analytical Strategy}

In this study, my main focus was on investigating the effect of teaching by using mobile learning in university student's achievement. The theoretical literature and previous studies related to the subject of the research were read to structure the study Instruments achievement. In Appendix, show the example Instruments used as final in the study.

\subsection{Instruments}

\subsubsection{Redevelopment of the Unit from an Introduction to Technology Courses}

The researcher redeveloped the unit from an introduction to the technology course to be taught in mobile learning, and the following mobile learning applications were used in teaching (Elearning system (moodel), 
whatsapp, youtube, facebook, SMS, mail, Bluetooth, web, pdf, Microsoft office, Live chat, twitter). The developed unit was implemented through a training program of 20 sessions and took one month to implement.

\subsubsection{Test of Achievement}

To determine the effect of teaching by using mobile learning in university students achievement, they have been Measured by the achievement test, the test consists of (25) question, type multi-choice, total score (100).

\subsection{Instrument Validity}

After the final preparation of the test, the researcher applied the test to a sample (10) Students with the aim of finding the difficulty and discrimination coefficients for test paragraph and the calculation of the validity and reliability of the test as well as the time required for the test to be applied. The validity of internal consistency was verified, by finding correlation coefficients (Pearson) between the score of each paragraph and the total score of the test, using the statistical program (SPSS), that all test paragraph achieved significant correlation with all score of the test at 0.05 , demonstrating that the test is internal consistency.

To verify the difficulty and discrimination coefficients for test paragraph, that the degree of difficulty of the test was between (0.45-0.54), and that the degree of discrimination between the test was between (0.67-0.49), indicating that all test intervals fall within the acceptable level For difficulty and discrimination.

\subsection{Instrument Reliability}

The researcher used the alpha-cronbach method to measure the reliability of the test as a first method to measure reliability, the coefficient of test reliability was finding using the alpha-cronbach, and the value of the total reliability coefficients is equal to $(0.898)$ which is its value high; this indicates that the test has a high degree of reliability.

\subsection{Data Analyses}

Using SPSS version 16.0, the researcher used mean, standard deviation and ANCOVA was used to compare the average scores of the students of the experimental group and the students of the control group in the test of achievement.

\section{RESULT}

To answer the main question: Is there a statistically significant $\alpha=0.05$ in differences between the average scores of the students of the experimental group and the students of the control group in the test of achievement? Mean, Standard Deviations and (ANCOVA) was used to compare the average scores of the students of the experimental group and the students of the control group in the test of achievement, as shown in the tables (1-4). The pre-test was applied to the study subjects to ensure the equivalence of the study groups as shown in Table 1.

Table 1. Mean and standard deviations to ensure the equivalence of the study groups.

\begin{tabular}{|c|c|c|c|c|c|}
\hline Group & Teaching method & \multirow{2}{*}{$\mathrm{N}$} & Mark & \multicolumn{2}{|c|}{ pre-test } \\
\cline { 4 - 6 } & & & & mean & Std.d \\
\hline Experimental & mobile learning & 25 & 100 & 10.56 & 4.14 \\
\hline Control & Traditional & 25 & 100 & 10.88 & 4.69 \\
\hline
\end{tabular}

Table 1. shows that there is a equivalence between the study groups, the mean of experimental group $(\mathrm{M}=10.56)$, control $(\mathrm{M}=10.88)$.

The mean and standard deviations of the students' marks were calculated on the testing of post-achievement according to the variable of the teaching method. Table 2 shows that. 
Table 2. Mean and standard deviations of the marks of the students on the test of post- achievement

\begin{tabular}{|c|c|c|c|c|c|}
\hline Group & Teaching method & \multirow{2}{*}{ N } & Mark & \multicolumn{2}{|c|}{ Post-test } \\
\cline { 5 - 6 } & & & & mean & Std.d \\
\hline Experimental & mobile learning & 25 & 100 & 85.12 & 6.78 \\
\hline Control & Traditional & 25 & 100 & 30.56 & 12.80 \\
\hline
\end{tabular}

Table 2. shows an apparent difference in the mean of student performance Course to test of post-achievement between the experimental group and the control, For the benefit of the experimental group, where the mean of the experimental group (85.12) and the control group (30.56). To illustrate the significance of the differences in the statistical averages of student scores at the level of $\alpha=0.05$, the analysis of the variance (ANCOVA) of the study individual marks was used to test the skills of post- achievement according to the group variable and the results of Table (3).

Table 3. The results of the analysis of the variance analysis (ANCOVA).

\begin{tabular}{|c|c|c|c|c|c|}
\hline Source & $\begin{array}{c}\text { Type III Sum of } \\
\text { Squares }\end{array}$ & df & $\begin{array}{c}\text { Mean } \\
\text { Square }\end{array}$ & F & Sig. \\
\hline Corrected Model & $37631.724 \mathrm{a}$ & 6 & 6271.954 & 58.439 & .000 \\
\hline Intercept & 3215.168 & 1 & 3215.168 & 29.957 & .000 \\
\hline Teaching method & 36130.479 & 1 & 36130.479 & 336.644 & .000 \\
\hline Pre-test & 421.804 & 5 & 84.361 & .786 & .565 \\
\hline Error & 4614.996 & 43 & 107.325 & & \\
\cline { 1 - 3 } Total & 209520.000 & 50 & & & \\
\cline { 1 - 3 } Corrected Total & 42246.720 & 49 & & & \\
\hline
\end{tabular}

a. $R$ Squared $=.891$ (Adjusted $R$ Squared $=.876$ )

Table 3. shows statistically significant differences at the level of $\alpha=0.05$ for the effect of teaching by using mobile learning in university students achievement. The value of (f) calculated (336.644), and the level of significance (0.000), this value is less than the level of significance $(0.05)$, there is a difference of statistical significance between the control group and experimental. The ETA squared of the teaching method is (0.891). It is clear that the effect of the use of the mobile learning on the achievement is very high, indicating the importance of this Compared to the traditional method of teaching.

Table 4. Shows effect size determination for values $(\eta 2, d)$

\begin{tabular}{|c|c|c|c|c|}
\hline Tools & Small & Moderate & high & Very high \\
\hline $\mathrm{d}$ & 0.2 & 0.5 & 0.8 & 1.10 \\
\hline$\eta 2$ & 0.01 & 0.06 & 0.14 & 0.20 \\
\hline \multicolumn{5}{c}{$\mathrm{d}=\frac{2 \sqrt{\mathrm{n} 2}}{\sqrt{1-\mathrm{n} 2}}$}
\end{tabular}

Table 4. shows that the values of the square eta $(\eta 2)$ field coefficient and the magnitude of the effect are significant, indicating that the magnitude of the effect of teaching by using mobile learning in university students achievement Very High. In summary for research question, the results showed that the mean in the traditional method scores were lower than the mean of the using mobile learning method in university students achievement. The effect size of the treatment was calculated using Cohen's $d$ and found to be $d=1.831$. This indicated that the mobile learning treatment had a "very high" effect, using Cohen's terminology, on the common final exam scores of the treatment group (Cohen, 1988).

\section{DISCUSSION, LIMITATIONS AND IMPLICATIONS}

The aim of this study was to knowledge the effect of teaching by using mobile learning in university students achievement. The results indicated that the mobile learning treatment had a "very high" effect. Indicating that there are differences of statistical significance between the average scores of students in the experimental group and control group in the achievement test, for the benefit of the experimental group. The researcher emphasizes that the method of teaching by mobile learning is a modern method and is rarely used in university teaching. In this study, I strove to explore the effect of teaching by using mobile learning in university student's achievement in course of pre-vocational education technology. Within the Bachelor of pre-vocational education program at shobak university college. I conducted the study under natural conditions in order In order to produce accurate results. 


\section{REFERENCES}

Al Tawarah, H. Mahasneh, O. Al-Hawartheh, N. (2017). The Effect of Practical Presentations' Strategy on the Achievement of the Ninth Graders Students of the Pre-Vocational Education Subject in Shobak District Schools. International Education Studies, v10 n5 p109-114 2017.https://files.eric.ed.gov/fulltext/EJ1142233.pdf.

Al-Monim, R. (2017). the effectiveness of smart phones employment in developing of self-learning skills and electronic communication among students of the Faculty of Education at Al-Aqsa University in Palestine. Zarqa Journal for Research and Studies in Humanities. 17(1), PP 97-111.

Chan, S. (2011). Becoming a baker: using mobile phones to compile e-portfolios. In N. Pachler, C. Pimmer \& J. Seipold (Eds.), Work-based mobile learning: Concepts and cases (pp. 91-117). Oxford, Bern, Berlin, Bruxelles, Frankfurt am Main, New York, Wien: Peter-Lang.

Cook, J. \& Pachler, N. (2012). Online people tagging: Social (mobile) network (ing) services and work based learning. British Journal of Educational Technology, 43(5), pp711-725.

Crescente, M. \& Lee, D. (2011). Critical issues of m-learning: design models, adoption processes, and future trends. Journal of the Chinese Institute of Industrial Engineers. 28 (2): 111-123. doi:10.1080/10170669.2010.548856.

Crompton, H. (2013). A historical overview of mobile learning: Toward learner-centered education. In Z. L. Berge \& L. Y. Muilenburg (Eds.), Handbook of mobile learning. Florence, KY: Routledge (pp. 3-14).

Jump, U. \& Cochrane, T. (2013). A Summary and Critique of M-Learning Research and Practice. ISBN 9780415503693.

Keegan, D. (2005). The incorporation of mobile learning into mainstream education and traning. IADIS International Conference Mobile Learning, Cagliari, Italy.

Mahasneh, O. \& Murad, O. (2014). Suggested Model (Related to the Student Portfolio) Used in Evaluation the Students in University Courses. Higher Education Studies; Vol. 4, No. 3. Doi:10.5539/hes.v4n3p72.

Mahasneh, O.Farajat, A.(2015).The Effectiveness of a Training Program Based on Practice of Careers in Vocational Interests Development. Journal of Education and Practice, v6 n26 p101-108 2015. https://files.eric.ed.gov/fulltext/EJ1077457.pdf.

Mahdi, H. (2016). The Effectiveness of Mobile Learning (SMS) Service in Acquiring and Retaining the Instructional Technology Concepts among the College of Education Students at Al-Aqsa University. AL-Najah University Journal for Research (Humanities). 30(5), PP 958-988.

Masters, K.; Ngambi, D. (2007). After the broadcast: disrupting health sciences' students' lives with SMS. Proceedings of IADIS International Conference Mobile Learning. Lisbon, Portugal. pp. 171-175. ISBN 978-972-8924-36-2.

Maxwell, J. (2006). Tracing the Dynabook: A Study of Technocultural Transformations. Koblentz, Evan. Abacus to Smartphone: The evolution of mobile and portable computing.

Mileva, N. (2011). The Effectiveness of Mobile Learning in the Form of Performance Support System in Higher Education. International Journal of Interactive Mobile Technologies (iJIM). 5(4):17-21DOI: 10.3991/ijim.v5i4.1692.

Moore, J. (2009). A portable document search engine to support off-line mobile learning. Proceedings of IADIS International Conference Mobile Learning. Barcelona, Spain.

Pimmer, C., \& Grohbiel, U. (2008). Mobile Learning in corporate settings. Results from an Expert Survey. Paper presented at the mLearn. The Bridge From Text To Context, Telford.

Pirttiaho, P., Holm, J. Paalanen, H. \& Thorstrom, T. (2007). Etaitava - Mobile Tool for On-the-Job Learning Paper presented at the Iadis, International Conference Mobile Learning, Lisbon, Portugal.

Saylor, M. (2012). The Mobile Wave: How Mobile Intelligence Will Change Everything. Perseus Books/Vanguard Press. p. 176. ISBN 978-1593157203.

Singh, M. (2010). M-learning: A New Approach to Learn Better. International Journal of Education and Allied Sciences. 2 (2): $65-72$.

Swan, K. (2005). Teaching and Learning with Mobile Computing Devices: Closing the Gap: 25-28. CiteSeerX 10.1.1.508.5837.

\section{APPENDIX}

An example of one of question from achievement test.

\begin{tabular}{ll}
\hline Who is the scientist proposed programmed education? & SID 11\} \\
& $\begin{array}{l}\text { Skinner } \\
\text { John Dewey } \\
\text { John Broadus Watson } \\
\text { Ivan Pavlov }\end{array}$ \\
\hline
\end{tabular}

